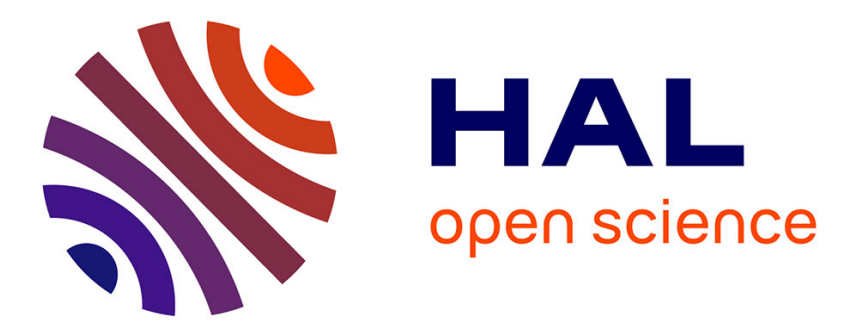

\title{
Governing street trading in contemporary cities. Anatomy of the policy instruments used by the City of Johannesburg in the post-apartheid era
}

Claire Bénit-Gbaffou

\section{- To cite this version:}

Claire Bénit-Gbaffou. Governing street trading in contemporary cities. Anatomy of the policy instruments used by the City of Johannesburg in the post-apartheid era. Urban Research and Practice, 2018, 11 (4), pp.396-425. 10.1080/17535069.2017.1374447 . hal-02780239

\section{HAL Id: hal-02780239 \\ https://hal.science/hal-02780239}

Submitted on 4 Jun 2020

HAL is a multi-disciplinary open access archive for the deposit and dissemination of scientific research documents, whether they are published or not. The documents may come from teaching and research institutions in France or abroad, or from public or private research centers.
L'archive ouverte pluridisciplinaire $\mathbf{H A L}$, est destinée au dépôt et à la diffusion de documents scientifiques de niveau recherche, publiés ou non, émanant des établissements d'enseignement et de recherche français ou étrangers, des laboratoires publics ou privés. 


\section{Governing Street Trading in Contemporary Cities Anatomy of the Policy Instruments Used by the City of Johannesburg in the Post-Apartheid Era}

A revised and edited version of this paper is forthcoming in Urban Research and Practice, 12(2), 2019 (available online)

\section{Claire Bénit-Gbaffou}

Center for Urbanism and the Built Environment Studies and School of Architecture and Planning, Wits University.

\section{Contact:}

Email: Claire.benit@wits.ac.za / clairebenit@hotmail.com

Address: Wits University, School of Architecture and Planning, Private Bag 3, WITS 2050, Johannesburg, South Africa

\section{Abstract:}

The paper interrogates how street trading is governed in contemporary cities of the South, based on the example of Johannesburg. It excavates policy choices made by municipal officials and politicians, understood through the set of policy instruments (policy documents, institutions and tools, but also non tools) that they have framed and used for almost two decades, beyond public rhetoric that is arguably misleading. The paper not only provides a critical analysis of policy instruments for governing street trading, scantly absent from existing literature; it also brings back into the urban studies debate issues of municipal officials' agency, political objectives and policy choices.

Key words: street trading, policy instruments, local government, urban management, Johannesburg 


\title{
Governing Street Trading in Contemporary Cities
}

\author{
Anatomy of the Policy Instruments Used by the City of Johannesburg in the Post- \\ Apartheid Era
}

This paper stems from a practical challenge I was confronted with as an engaged academic in the troubled aftermath of 'Operation Clean Sweep', an operation in which the City of Johannesburg in November 2013 brutally evicted about 7000 sidewalk traders (authorized and unauthorized alike) from the inner city. The City was subsequently compelled by the Constitutional Court to reverse its actions and engage with traders. I and the Centre for Urbanism and the Built Environment Studies (CUBES) at Wits University (the research Centre to which I am affiliated ${ }^{1}$ ), were approached by street trader organisations to assist in proposing alternative, progressive management models for street trading to the City of Johannesburg. During this process I coordinated a series of workshop with traders, as well as facilitated the active participation of CUBES in the public debate around municipal draft policy documents. The practical and immediate challenge to developing an in-depth understanding of existing street trading policies and instruments, and to proposing realistic alternative models (in discussion with traders and officials), led me to conduct dedicated research on management models for street trading (Author 2015). I quickly established that there was a paucity of international documentation (best practices, or even just case studies) and research (reflection and theorisation) on the specific issue of the street trading management and its instruments. This quest for practical and academic knowledge on how street trading is governed, and the interrogation on why such knowledge is so scarce, motivated this paper: a reflection on how to understand the (elusive) government of street trading, through the case of post-apartheid Johannesburg.

To more accurately define the gap, let me acknowledge the vast academic literature on street trading policy (on the one hand), which analyzes strategic public documents stating broad principles on the place of street trading in national and local economies (Bromley 2002; Rogerson 2009; Lyons and Brown 2009; Pezzano 2016), and the even broader literature on street trading governance (on the other hand), which unpacks street traders' resistance from below and the multiple ways in which they interact with municipal officials, generally animated by repressive approaches to street trading (Bayat 1997; Lindell 2010, Kamete 2010; Anjaria 2011). The gap lies in understanding the internal practices, constraints and choices of municipal officials - a view from inside the state, as opposed to a view from above (the public policy view), or from below (traders' experiences and the difficult interface, comprising contestations and negotiations, with local authorities). We need to more clearly delineate the complexities and contradictions, as well as the choices - the overt or covert objectives - of state agents when attempting to govern street trading. This is not to assert that these choices occur in isolation from political, social and urban contexts, without interaction with other stakeholders like business and residents groups or organized and unorganized trader groups. However the sole focus on policy rhetoric (which I argue is increasingly emptied of its

\footnotetext{
${ }^{1}$ The Centre has a tradition of engaged research (see also note 7 below).
} 
meaning), or on the everyday messiness of implementation (often assuming the state as a unified and generally evil entity), is opening an analytical gap. This gap comprises the actual practices and choices made by government officials, in a context framed by specific institutions, policy instruments and internal politics, which we call the government (as different from the policy or the governance) of street trading. This paper hopes to map and begin to address this through the case of Johannesburg.

The paper starts with locating the government of street trading into a broader debate synthesizing existing knowledge from literature, interrogating more broadly why it appears under-researched, and suggesting a closer analysis of policy instruments (their framing and their use) in the understanding of the way municipalities govern (or don't govern) street trading. The paper then examines and unpacks three types of interrelated policy instruments set up and used by the municipality of Johannesburg to govern street trading since the late 1990s. It concludes with a reflection on the strategic dimension of seemingly technical decisions governing street trading, arguing that excavating hidden or blurred policy choices is a necessary step to start imagining alternative paths, in Johannesburg and elsewhere.

\section{What We Know (and Don't Know) About the 'Government' of Street Trading}

There is a daunting profusion of literature on street trading in cities of the South, and yet also a frustrating scarcity when one looks for more specific analyses of how street trading could be governed differently to the current mix of repression and laisser-faire that has been witnessed for centuries in cities across the world. This section attempts to summarise what is known about the government of street trading, and also question why we seem to know so little.

\subsection{Policy, Governance, Government, or Management of Street Trading?}

The concept of governance refers to the understanding that a number of stakeholders are involved in governing the city - not solely the state (see Box 1). It marks a paradigm shift in policy and urban studies, generalised in the 1990s, away from a sole focus on local government to understand how cities are really governed, and imply the study of governance networks, and the relationships between local government and other (business and civil society) stakeholders. These approaches however, have arguably missed a reflection on the policy instruments, institutions and practices of government officials - marked by governance dynamics but still also determined by internal state logics (Author forthcoming). This neglect might have in some cases been compensated by other fields of academic studies (such as policy studies, public administration studies, or anthropology of the state), however with limited articulation with governance and urban studies. These gaps are particularly glaring in the realm of street trading.

The politics and governance of street trading has become a vast field of research: politicizing and localizing in urban space a literature on informal activities that was dominated by economic approaches (Lindell 2010) - including, in particular, studies on trader livelihoods, micro-economic activities, local economic development and poverty alleviation strategies. This shift has led to question how street trading is governed, but analyses remain based 
mostly on visions from 'outside' the state, through the study of its broad policy guidelines and public documents (what I called here the policy approach ${ }^{2}$ ), or through the analysis of the complex interface between traders and municipalities (what I call the governance approach ${ }^{3}$ ).

\section{Box 1 - Operational definitions: governance, government, management of street trading}

The governance of street trading - The ways in which a variety of stakeholders, beyond the state, intervene through negotiations, contestations, alliances or opposition, in governing street trading.

The government of street trading - The intentional, strategic directions given by relevant stakeholders (through a variety of policy instruments and practices) to govern (plan, shape, and manage) street trading in the city.

The management of street trading - the norms, rules and usual practices that frame and regulate the way street trading takes place every day in the city. Street trading management is part of the government of street trading, however focuses on how the sector is regulated locally on an everyday basis, more than on what strategic direction street trading is taking as a sector of activity or realm of urban development.

In cities of the South, street trading policy is usefully approached through a medium- or longterm historical perspective (Bromley 2002, Kusakabe 2006, Roever 2006, Lyons \& Brown 2007, Rogerson 2009, Skinner 2008, Tissington 2009). Most of this literature stresses the dominant repressive approach to street trading by municipalities across the world, in tension with national agendas in developing countries. Indeed, these national agendas, in line with global institutions, have often shifted towards embracing street trading as a permanent feature of cities of the South (Pezzano 2016). But these national policies often treat street trading mainly through an economic lens, as an emerging economic activity and a poverty alleviation mechanism that require mostly business support and regulation (Lyons \& Brown 2007, Author 2015). This economic take has limited relevance for municipalities, which are primarily faced with the challenge of managing the conflicting land uses generated by street trading encroaching on public space, and for which national or global economic visions are unable to provide guidance or support.

The planning discipline and broader policy studies are often more centrally interested in interrogating, sometimes normatively, how the state governs, plans, or manages areas and sectors in the city. However, the realm of street trading is generally absent or scarce in planning theories. Modernist planning theories conceptualize urban informality as an inheritance of the past, a sign of backwardness or underdevelopment, expected to disappear with modernization (based on experiences from the North). These theories do not sufficiently consider the challenges posed by mass poverty, chronic unemployment and large inequalities that mark the contemporary world, and cities of the South in particular (Benjamin 2004, Kamete 2013). Modernist planning thinking is often invoked by officials in street trading policy debates: around the need to formalize or restrict sidewalk trading; around statements arguing that there is a limited number of street trading spaces in a given city (and that this

\footnotetext{
${ }^{2}$ In a narrow sense, as these studies often are empirically restricted to the study of public policy documents, due to the difficulties in accessing more internal policy dynamics that I capture here under the concept of 'policy instruments' (including but not limited to public policy documents).

${ }^{3}$ This term is tricky, as it refers both to a concept in urban studies (see Box 1), and a body of work (the 'governance approach') that I argue has focused predominantly on networks and less on policy instruments, choices and their impacts on the city.
} 
number can be scientifically determined); or to push for the relocation of street traders into markets, even if evidence from cities of the South shows that they have generally failed to contain and support traders (Mitullah 2005, Roever 2006, David et al 2013). Postmodern planning, more flexible in its intention - adopting the principles of strategic planning, mixed land uses and incrementalism - has also not addressed the issue fully. Focused on defining strategic directions, it has seldom constructed the instruments needed to implement them, nor considered the important resources that flexible, area-based, locally-adapted and participatory planning would require. As I will argue below, these strategic directions are generally at odds with policy instruments geared towards restricting the number of existing traders, rather than accommodating them.

Unlike other areas of policy and planning interventions - such as housing or transport in the field of urban planning, but also the environment, immigration, or other sectors of state intervention in the field of policy studies - street trading has not seen the development of focused debates on policy instruments and strategies, possibly because these are considered insignificant as state intervention, requiring limited sophistication in terms of policy instruments. Literature on local economic development (including small and medium enterprises policy support) has also overlooked street trading, probably because it is considered of marginal strategic or developmental value. Furthermore, the weak capacity of street traders to organize as a movement (Lindell 2010) has possibly restricted their ability to frame street trading as a 'public issue' requiring dedicated public intervention. Other basic needs are seen as more urgent areas of state intervention in cities of the South, where street trading only crystallizes state intervention when it becomes too visible, in specific spaces and specific moments. The paradigm shift that has marked international thinking on informal settlements - from denialism and eradication to in-situ upgrading (Huchzermeyer 2011) - has not occurred in the field of street trading.

Literature on street trading governance, on the other hand, focuses more centrally on the multiple engagements between traders and the state. The municipal failure to govern street trading is here demonstrated from traders' experience and their practical encounters with the state, and is read less as a 'failure' than as an actual mode of regulation and management of the everyday, based on a mix of clientelism, delegation and repression (Bayat 1997, Lindell 2008, Anjaria 2011, Kamete 2013). In this respect, street trading seems to only be managed: state intervention is mainly about setting up technical systems to mitigate the nuisance that street trading is understood to generate in the urban realm, to possibly tax some of its economic profits, and to sedate or fragment opposition by selectively legalizing a minority of traders (Pezzano 2016) or developing (intentionally or indirectly) forms of trader acquiescence and identification in the project of neoliberal governmentality (Wafer 2011, Morange 2016). In this view, there is limited room for governing (in the sense of steering) street trading, except when it comes to its attempted (and partly failed) eradication, repression or restriction.

This diverse body of literature converges in stressing the partial failures of the implementation of restrictive policies: their inefficiencies, inconsistencies, and the chronic resistance of street traders to being governed. However, the state arguably remains 'a black box', 
'implementation failure' a mystery, and the nature of the policy instruments used by municipalities to implement their policies and adapt to their chronic failures are left under the radar of research. This opacity of state instruments limits the capacity of researchers, activists and professionals to contest existing visions and frame alternative ones.

\subsection{Why are restrictive municipal approaches dominating the government of street trading?}

Why are restrictive and repressive approaches dominating the government of street trading, at least in what is documented in the existing literature? By restrictive, I refer to an approach aimed at curtailing the number of existing street traders (creating a significant gap between the number of authorised trading sites, and the number of actually existing traders), whilst a repressive approach is defined here as dominated by the (legal or physical) tracking and sanction of illegal practices in which users might engage in the pursuit of their activities.

Some authors highlight the lack of political imagination of municipal officials when it comes to the governance of urban informality (Skinner, 2008). By-laws inherited from the colonial past, which were precisely attempts to contain informality, 'the Natives' and poverty out of city centres, are often remobilized or reinvented by post-colonial authorities, after their brief suspension during liberation (Morange, 2015a). Further, the scarcity of documentation and theorization on street trading government makes it challenging for officials to embark on a different, inclusive approach, as managing traders in dense and diverse streets remains more complex than managing traders contained in a market. In the latter they are bounded and fixed, formalized to some extent, easier to tax, more unambiguously identifiable as business people, and generating slightly more substantial profit (Author 2015). In this respect, literature on street trading management or on the government of the informal economy is often, misleadingly, focused on market management (Kumar 2012, David et al 2013), as if markets were the only solution to street trading management challenges.

A second line of argument stresses the vested interests of City officials caught in patronage and corruption networks (Lindell \& Appellblad, 2009), which partly explains the state's internal resistance to change and to the exploration of alternative approaches (away from restrictive practices). Such vested interests are grounded firstly in the rent derived from what I call 'the public production of scarcity' (an effect of adopting a restrictive approach): the planned and deliberate restriction of legal trading sites by the state which, contrasted with existing trading sites, opens opportunities for corrupt practices (from clientelism to bribery, arbitrary application of the law, and bouts of violence). It can also be linked to the politiciandeveloper-speculator nexus, where officials are part of a growth coalition generally unsympathetic to informal trading, considered a symptom and a cause of urban decay.

This is not to say that progressive practices ${ }^{4}$ towards street trading do not exist, even if they are not formalized or presented as such, and sometimes are restricted to specific spaces in the city. In many African cities, street trading is often seen as a category of trading, understood

\footnotetext{
${ }^{4}$ A progressive approach to street trading is defined as combining inclusivity (recognising existing users as legitimate stakeholders; engaging with them in the definition of policy goals and implementation; not based on the eviction of significant numbers of existing traders, i.e. not restrictive) and development (dominated by the desire to assist recipients to develop, rather than sanction them - i.e. not predominantly repressive).
} 
along several degrees of formality. It is often subjected to municipal taxation ${ }^{5}$, the limited level of the tax being compensated by the large number of traders taxed. It contributes to municipal income in significant proportions, as trading is a key activity in often underindustrialised African cities, and where national transfers to local authorities are far more limited than in the South African context. Other discrete work documents the participation of street traders in the management of the street, their legalisation and consolidation as legitimate stakeholders, and even partners, in the construction and management of urban space $^{6}$. For example, the construction of progressive (inclusive and participatory) legislation based on pilot innovative practices in India, at all levels of the state, is the focus of much academic interest (Kumar 2002; Grest 2008; Sinha \& Roever 2011; Author 2015; Matjomane 2016).

\subsection{Is street trading ever governed, or is it just managed?}

Some officials in the City of Johannesburg present street trading as 'an intractable issue' - a sector of society that it is simply impossible to govern and an area of policy intervention that is doomed to fail. While it is this paper's argument that street trading can be governed, officials' reflections highlight challenges that are linked to specific characteristics of this sector. From the vast literature analyzing the economic, political and urban dynamics of street trading in cities of the South, one can extract a number of specific characteristics of the sector which arguably render its government daunting. The paper groups these characteristics in three sets, each relevant to one specific challenge to the government of street trading.

The first characteristic is the spatial, economic and social fluidity of street trading as a sector of policy intervention. Street traders are often physically mobile in space and time (Bromley 2000), as they follow customers' foot traffic (in daily, weekly, monthly and seasonal peak times) and might also adopt mobility tactics in response to private or public security forces' patterns of surveillance. Moreover, street traders are not a fixed cohort (Dimas 2008): many come in and out the sector depending on formal employment opportunities, although in times of chronic slow growth many are trapped in this activity. This fluidity contributes to render street trading difficult to manage (Simone 2004) - partly escaping municipal attempts to measure, categorize, and identify (Roever 2011) or to regulate and tax, and where one-sizefits-all regulations are likely to have destructive and unintended consequences.

The second set of characteristics refers to the fragmentation and fragility of street trader mobilization. This fragmentation stems first from street traders' individual economic fragility, with a majority of them being survivalist entrepreneurs, relying on 'quiet encroachment' as the most efficient way to secure their activity (Bayat 1997) rather than overt mobilization (that some authors however argue is rising: Lindell 2010). Street traders' fragile mobilization might also have spatial explanations (Author 2016): unlike residents groups, street traders do not form a political constituency for local, area-based elected representatives. Unlike formal workers, they do not have an employer to pressurize nor a bounded workplace forming a

\footnotetext{
${ }^{5}$ See for instance mentions of this in a case study of the management of markets in Pikine, Senegal (Ngom, 2002).

${ }^{6}$ See for instance a short lived example of a street trader cooperative managing a street in Dar es Salaam, Tanzania (Nnkya 2006).
} 
strong spatial basis for collective mobilization. Finally, street trader mobilization is often limited by the fact that street traders are both oppressed and marginalized by their informal status and economic fragility, and are entrepreneurs in competition with one another, aiming ultimately at limiting the number of street vendors in their area (Author 2016). This fragility of organisations and movements weakens their ability to shape the public agenda or to develop alternative policy models and instruments (beyond stopping municipal harassment) which could be advocated or negotiated with public authorities.

The third set of street trading characteristics that explain the challenges in its government is closer to the scholarly definition of 'intractable problems', those seeming 'to defy resolution and obstruct critical debates about a problem situation, because the involved actors not only have different ideas about the issue involved, but also disagree about the very issue at stake' (Scholten 2013). This is the case between different municipal departments; between different levels of the state; and also between various civil society stakeholders intervening in public debates. Firstly, the government of street trading in most countries falls under a diversity of departments (Lund \& Skinner 2004). It is generally located within economic development departments, although many traders are understood to be 'survivalists' and could fall under social services. The government of street trading also entails a crucial land use dimension (as an encroachment on dense and multi-use public space), which often means it falls functionally under planning departments. In the colonial past it used to sit under police departments (Skinner 2000) and police enforcement of municipal by-laws still plays a crucial role in its management. Secondly, the government of street trading is also shared between different layers of the state, at least between national and local (Bromley 2002, Roever 2006, Lyons \& Brown 2007, Rogerson 2009). The policy objectives of various spheres of government do not always coincide. In South Africa, while policies at national level tend to see street trading as a form of poverty alleviation that should not be destroyed, local authorities are confronted by urgent land use management issues, where street trading, particularly in inner cities, is considered a nuisance, generating additional litter and congestion on the streets (Matjomane 2013, Pezzano 2016). Finally, competing framings of the nature of the 'issue' at stake (directly observed during public meetings in Johannesburg, but also echoed in international literature) have rendered public debate difficult amongst civil society groups: is street trading the issue (and therefore should be banned altogether from prime urban space) or is the issue its 'unmanaged' status (so it should be accepted but efforts should focus on its regulation)? Is street trading conceived as a survivalist activity (and its acceptance a form of social welfare) or an entrepreneurial one (and its government geared towards formalisation and up-scaling)? Is street trading offering a specific retail service (accessible and affordable) or is it competing and undermining formal businesses? Is it part of the public function of an African street, or is it a form of privatisation of public space? Fundamental misunderstandings and disagreements have marked public debates involving a multiplicity of stakeholders, weakening the possibility of alliances and compromises. The government of street trading is therefore torn between several priorities and ways of framing the issue, between different layers of the state, different municipal departments, and different civil society stakeholders, which undoubtedly makes it a complex area to govern and to regulate. 
These sets of characteristics might provide some reasons why street trading, from a local government perspective, seems more often managed than governed. Why it is regulated on an ad hoc, everyday basis (tolerated whilst it is trying to limit its expansion, encroachment and visibility) rather than proactively framed and included in broader strategic thinking, urban policies, designs and plans. Policy directions remain inconsistent or ineffective; officials' practices adapt to circumstances - the political urgency of the moment, levels of organisation of resistance from traders, engagement with private sector lobbies or (mostly) informal everyday arrangements - without a clear sense of a policy direction, of formalised instruments constructed to deal with policy goals and the reality on the ground. This might explain why the government of street trading features so little in existing literature and documentation and why literature on its management remains patchy and inconsistent.

\subsection{The quest for in-depth analysis of policy instruments to govern street trading}

Paying closer attention to municipal choices, processes and instruments in the government and management of street trading is a more recent area of analysis (Lund \& Skinner 2004, Pezzano 2016, Morange 2016). However it is limited by the empirical difficulty in accessing officials' perspectives and practices in such a contested terrain of urban governance.

Indeed, entering the 'black box' of the state through direct, ethnographic observation is even more daunting than usual in the informal trading sector. Given dominant restrictive practices and ongoing contestation from civil society (including increasing litigation), officials are wary of research that is seen as potentially consolidating a politics of contention ${ }^{7}$. Besides, the gap between the limited legal trading sites offered by the City, and the mass of existing traders actually trading, structurally opens a space for corrupt practices, which probably reinforces officials' reluctance to any outsider gaze.

For this paper, the in-depth analysis of policy objectives and instruments was made possible by a long-standing involvement in action-research in the field of street trading in Johannesburg (as with Lund \& Skinner 2004, for instance) and a space of intense engagement paradoxically opened by the crisis of Operation Clean Sweep, that assisted in going beyond the public rhetoric that is, arguably, masking the reality of state practices and objectives. As the director of the community-oriented research initiative Yeoville Studio (2010-2012) ${ }^{8}$ I had initially been involved in coordinating a research group ${ }^{9}$ investigating progressive management principles for street trading, in response to a request from local trader leaders. This request was reinvigorated after Operation Clean Sweep, where it led to a series of

\footnotetext{
${ }^{7}$ This was experienced firsthand by the author in the aftermath of Operation Clean Sweep in Johannesburg, where the City-led evictions were followed by a series of court cases led by trader organisations, ending in their victory against the city in the Constitutional Court in 2014. However difficulty in accessing information, documents and officials pre-existed this legal battle.

${ }^{8}$ Yeoville Studio was a community-oriented research initiative (2010-2012) where CUBES and the School of Architecture and Planning partnered with three civil society organisations in Yeoville, to frame locally relevant research, by coordinating teaching and research initiatives around jointly determined topics. See https://www.wits.ac.za/archplan/interdisciplinary-engagement/yeoville-stories----yeoville-studio/

${ }^{9}$ I wish to thank here a number of colleagues and students whose research has contributed to framing a collective body of knowledge on the sector, emerging from the Yeoville Studio: in particular Aly Karam, Mbula Khwashaba, Kwanda Lande, Mamokete Matjomane, Antonio Pezzano, Margot Rubin, as well as Marie Daniel and Kate Tissington.
} 
monthly workshops with seven inner city-based street trader organisations aimed at discussing official documents, framing counter proposals, building joint submissions, and participating with the traders' coalition in City-led participatory processes. I was further included in a University-wide project contracted by the City of Johannesburg in $2014^{10}$, with the intention for academics to provide direction to the City on a way forward after Operation Clean Sweep. For this project, beyond debates with colleagues, I conducted and supervised studies on street trading management models (Author 2015, Lande 2015, Khwashaba 2015), which were presented and debated with traders and City officials. Through these engagements, which were marked by levels of antagonism and distrust, I nevertheless gained a degree of understanding of officials' views, concerns and practices, but also actual tools of intervention, beyond the publicly accessible documents. It is this research and practical experience that I will partly present and analyse here, framed through a typology of policy instruments understood in their articulation.

A broad variety of categorization of policy instruments is offered by the abundant literature on policy instruments, which I read, for the purpose of this paper, as structured between three positions: what I would call 'functionalist' analyses (unpacking instruments' efficiency as tools to achieve policy objectives in specific areas of state intervention), 'meta' analyses (reflecting on the nature of policy instruments and their evolution over time, especially in the era of globalizing and neoliberalising governance), and 'genealogic' analyses (emphasizing the politics of policy instruments' elaboration as key to understand policy objectives, beyond the increasing ideological and rhetorical vagueness of public policy documents). I am locating my paper mostly in the third body of literature, but borrowing concepts from the three.

A useful set of categorizations differentiates instruments according to their level of coerciveness (or state intrusiveness) over society (captured in the powerful tryptic: 'carrots, sticks and sermons' proposed by Vedung, 1998). Many argue in this regard that state's interventions are shifting towards less coercive, more incentivizing and participatory instruments (Linder \& Peter, 1989). Whilst policy instruments increasingly require degrees of acquiescence and appropriation by their target groups, I find important to analyse the set of instruments as inter-related and multilayered, fundamentally playing on a mix of coercion and incitation to attempt to shape social and spatial dynamics: the latter not replacing the former. Looking at a variety of policy instruments as a system (not devoid of contradictions but with a degree of sustainability and interdependence) helps unpacking policy objectives, beyond the classic and broad 'policy-implementation gap' analysis - which, I argue, is disempowering both analytically and politically (Author forthcoming). Furthermore, some authors propose to distinguish instruments according to their scale or level, and to their nature. Debates abound on whether institutions geared at implementation of a policy should be considered policy instruments (Peters, 2000; Hood, 2007). I consider them to be, importantly so: institutions are particularly revealing of the policy objectives prevailing at the time of their setting up, structurally embodying and shaping officials' practices; their persistent lack of reform (even

\footnotetext{
${ }^{10}$ AFTRAX, Alternative Formalities, Translocalism and Xenophobia. I wish to acknowledge here the colleagues involved in the project, which provided a stimulating environment to debate and consolidate ideas (mistakes and interpretations remain mine): Sarah Charlton, Margot Rubin and Tanya Zack in particular.
} 
when policy discourse changes) questions the depth and authenticity of policy change. Other authors offer typologies of instruments according to their scale of operation. Lascoumes and Le Galès (2007) distinguish between instruments, techniques and tools. To some extent, I adopt here a classic division of policy instruments between policy documents (those providing with statement of intentions, broad guidelines for intervention, defining objectives and aims); institutions (bounded organisations with internal rules, responsible for the area of intervention under study: their framing, their staffing, their reports and budgets); and tools (more minute, technical, material instruments at the direct interface between policy implementers and recipients).

But I would add to this typology an interrogation that is more specific to the object of study, and leads to an internal differentiation amongst policy documents: the extent to which they are public, in the sense of involving public participation processes in their elaboration, and of being easily accessible to members of the broader public (posted on the web for instance). In this respect, I distinguish three degrees of publicity amongst what I call 'policy documents' (in a broad sense of the term: offering principled directions and guidelines): public policy documents (those called 'policy', 'strategy' and 'by-laws', widely available to the public, and which have been subject to public participatory processes); action plans and guidelines that are only partly public (Council resolutions that are public in theory but seldom accessible in practice; formal or informal agreements between state and non-state stakeholders that are not visible to the broader public but only to the groups engaged). Finally, there is a whole set of non-public guidelines that it is difficult not to consider 'policy': internal strategic guidelines for officials, that are not public documents but offer broad policy direction to officials, and are often far more precise in the expression of objectives than public policy documents. The next section will build on this typology of policy instruments to understand the system they form, to govern street trading in post-apartheid Johannesburg (1999-2016).

\section{Multi-Layered Policy Documents: Progressive Public Rhetoric, Restrictive Internal Discourse}

Informal trading policies in Johannesburg have already been thoroughly documented by other authors (Rogerson 2007, Tissington 2009, Dinath and Zack 2014, Author 2015, Pezzano 2016) ${ }^{11}$. My argument in this section is two-fold: first, it is to show that, beneath the shift towards more progressive public policies, and beyond what has been described by these authors as discontinuities, inconsistencies or implementation gaps, there is in fact great continuity in a municipal restrictive approach. This continuity is clear when one differentiates what are called 'policy documents' (understood as those which give broad and strategic directions to guide officials' practices) into, on the one hand, documents that are public and publicized (aligning to progressive discourses) and, on the other hand, those documents which are less publicized, sometimes internal guidelines within the City (consistent in their restrictive intention). This is not to say nothing has changed; however the rhetoric shift in

\footnotetext{
${ }^{11}$ Johannesburg is considered South Africa's economic capital. In 2011 it counted 4,4 million inhabitants (2011 Census). It is estimated that $23 \%$ of its active population is involved in the informal economy in 2013 (36\% if including self-employed workers) (Peberdy 2015).
} 
public policy documents is not reflecting nor driving a shift in the real policy objective of the City.

\title{
2.1. A rhetoric shift in public policy documents - from restrictive to progressive discourse?
}

Municipal legislation on street trading emerged in Johannesburg in the late 1990s, a response to the post-apartheid national legislation which opened up inner cities to traders who had been excluded from it for decades (Rogerson, 2000). However this legislation left municipalities ill-equipped to face the proliferation of unmanaged street trading in their dense urban centres.

The national Businesses Act of 1991 (amended 1993) is indeed favorable to street traders, allowing street trade anywhere except in restricted or prohibited areas - as opposed to allowing street trade only in specifically-defined vending zones. Importantly, the Act makes it clear that the prohibition and restriction of street trade can only take place after a process of engagement with street traders affected by such limitations, which demonstrates that other options than restriction were envisaged, and discarded (1993 Business Act: 6A.2.c.).

In contrast with the permissive objectives of the national level Act, the City of Johannesburg started enacting restrictive policies in the late 1990s. This was a response to local practical challenges of managing the dense inner city and busy streets, but also to notable national economic policy shifts (from a redistributive to a growth-oriented agenda) and to President Thabo Mbeki's 2003 stance on the 'second economy'. In line with liberal economic visions (De Soto, 2000) he argued that informal activities constituted a 'second economy' not sufficiently linked to the 'first' (formal) economy, framing the vision of an informal sector simply waiting to be uplifted and formalized to foster economic growth and development (Rogerson, 2007; Skinner \& Valodia, 2006). This stance is reflected in the City of Johannesburg's restrictive vision of street trading at the time:

\begin{abstract}
An informal sector will continue to exist but will be substantially reduced in size and fundamentally different in character. Survivalist informal sector operators will either no longer be resident in the City or will have found secure formal sector employment. Remaining informal traders will operate as such by choice rather than by necessity $[\ldots]$ The $[\ldots]$ requirements in respect of the supply of informal retail trade is to make the whole of Johannesburg without exception a restricted trading area in terms of existing by-laws. (GJMC, 2002: p. 111 and 84 respectively, my emphasis).
\end{abstract}

This vision informed the by-laws and plans developed by City officials during this period. The 1999 Inner City Informal Trading Management Plan, From the Streets into Markets (GJMC, 1999a), was unambiguous in its intention to relocate all street traders into newly developed markets. In line with this plan, a resolution was passed by the City Council in 1999 that restricted street trading in almost the whole of the Johannesburg inner city (GCMC, 1999b). Like all public and legally binding documents, it went through a public participation process. It was highly contested by trader organisations, with no effect on the ultimate framing of the document.

During the late 1990s to early 2000s, many neighborhoods and high streets experienced the forceful eviction of street traders, sometimes relocated into markets. The 2004 Street Trading By-Laws corroborated this vision of street trading as a nuisance, with a document exclusively 
focused on prohibiting, restricting, impounding, removing, inflicting penalties, and stating street traders' duties in terms of behavior in public space, cleanliness and other responsibilities (CoJ 2004).

Radical academic and political criticism of the City's Joburg 2030 strategy (which coined it 'neoliberal') and rising political unrest in response to iGoli $2002^{12}$ shattered the image of the City of Johannesburg as a progressive, poor-oriented City ${ }^{13}$. With the 2006 local elections approaching, the urge to reframe the City, the local ANC and the Mayor's image in more progressive terms, affected the way in which the informal economy was presented in official discourses. Matjomane (2013) and Pezzano (2016) trace this significant rhetorical shift, from restrictive policy discourses and documents in the late 1990s and early 2000s, towards the acceptance and legitimation of the importance of street trading in a number of official documents from 2006 onwards.

The 2006 Growth and Development Strategy (GDS), a strategic document aimed at reconstructing a shared progressive vision for the city, proclaims as one of its key principles the 'Proactive Absorption of the Poor'. The 2007 Informal Trading Policy, as well as the revised 2009 Informal Trading By-Laws, recognize the contribution of the informal economy to job creation and poverty alleviation. The latter even mentions the constitutional 'freedom to engage in informal trading' (CoJ 2009: 4). The 2007 Policy further introduces sections on the training and mentorship of traders, support for business incubation and cooperative formation, and consultation (CoJ 2007: 14, 15 \&17). This developmental direction is echoed in the 2007 Inner City Regeneration Charter (a broad participatory process aiming at rejuvenating government and civil society's dialogue and partnership in regenerating the inner city), as well as in the 2011 GDS, which further warns against about the potential destructive effects of municipal regulatory attempts, seen as necessary, but requested to adopt more sensitive, developmental and flexible approaches (CoJ, 2011: 25, quoted in Matjomane, 2013). The 2013 Inner City Road Map, a continuation of the 2007 Charter process, reiterates this official position, suggesting new institutions to manage inner city spaces and area-based approaches to find adapted solutions to street traders' management. However no document fundamentally challenges the status quo in terms of regularizing existing traders, expanding legal trading spaces or contesting the dominance of markets as legitimate trading spaces.

This shift also reflects the influence of progressive officials in the crafting of City policy documents, in particular those based in the Central Strategy Unit (CSU), an advisory department to Mayor Amos Masondo between 2000 and 2011. The CSU gathered a number of former struggle activists, closely networked with progressive academics and consultants, who played a key role in facilitating internal debates, consolidating key principles and embedding them in strategic documents and mayoral discourses. Arguably under the new Mayor, Parks Tau, and with new staffing, the CSU has lost some of its influence. Operation

\footnotetext{
${ }^{12}$ iGoli 2002, inspired by the Joburg 2030 strategy, implemented the restructuring of Johannesburg municipality in the early 2000s along new public management principles.

${ }^{13}$ Interview with City official, City of Johannesburg: Central Strategy Unit, June 2013.
} 
Clean Sweep, spearheaded by Mayor Tau and his Mayoral Committee members ${ }^{14}$, supported by ad hoc operational teams nominated by the Mayor, testify to such a shift.

\subsection{Less publicized policy documents: continuity in the municipal restrictive approach}

Since the end of the 1990s and the first street trading restriction (GJMLC, 1999b), the City through its Economic Department Unit (EDU) ${ }^{15}$ - has however continuously attempted to limit the number of traders on the street, even after the mid-2000s policy shifts. It has prohibited major parts of the inner city for street trading, authorizing only a limited number of street traders with the aim of eventually relocating them into markets in the short to medium term. ${ }^{16}$ A 2005 internal strategic document in EDU confirms the City's commitment to a restrictive approach (never explicitly mentioned in public). Comparing Johannesburg to Durban's policies towards street trading, it states:

In researching global best practice, the City of Durban is rated very highly. However, [...] Durban's Informal Economy Policy [...] was in fact much more liberal than the current CoJ proposals and was certainly not looking to restrict street trade but rather to encourage and manage it. (EDU 2005: 7, my emphasis)

This restrictive vision was translated in a 2005 Council Resolution, extending the 1999 street trading restriction to 'the remaining of the inner city' and to City Improvement Districts (CIDs), whose boards were given the right to 'approve the placement of informal traders in their areas prior to permission be granted to informal traders by the CoJ' (CoJ 2005). In a similar vein, EDU proposed a 90 day action plan in 2006, in partnership with property owners (Central Johannesburg Partnership, ${ }^{17}$ in particular) to 'clean' Bree and Jeppe street (two central streets in the inner city), reiterating its intention to ban 'pavement trading' (EDU 2006).

The revised Informal Trading Policy that followed in 2007 acknowledged the permanence of traders in the street and, in an attempt to better manage traders and their needs, made provision for the issuing of smart cards to street traders in which their trading status and preferences would be registered (CoJ, 2007: section 9). However, the policy remained silent on who should be allocated smart cards and on what basis, with no indication of whether a restrictive or inclusive approach would be chosen. This was not clarified by the 2009 City ByLaws on Informal Trading which confirmed the Council's unilateral power to designate, restrict or prohibit trading areas, with no indication of process and engagement with stakeholders, and where the City reserves the right to not provide feedback on its decisions (CoJ, 2009: 6.2). Overall the by-laws focus mostly on municipal control over traders and bylaw enforcement, rather than on developmental issues (Matjomane, 2013).

\footnotetext{
${ }^{14}$ See the list of the state institutions, departments and agencies mentioned in the text, in the Annexure.

${ }^{15}$ Reframed as the Department of Economic Development in 2006.

${ }^{16}$ A noticeable exception in 2004 was the sudden and contested roll-out of 1000 trading stalls (called the iron cages') in inner city streets (Dinath \& Zack 2014), in contradiction of rules and without any consultation with property owners or traders. I understand it as the possible expression of strong, once-off political pressure i.e. 'letting the steam off', however it has not significantly changed the municipal approach.

${ }^{17}$ The Central Johannesburg Partnership (CJP) is a non-profit coalition of business people and private companies grounded in inner city Johannesburg, and dedicated to the regeneration inner city, in partnership with the City, since the early 1990s.
} 
Operation Clean Sweep further fed into this vision that street traders are merely tolerated. The Operation stemmed from a report prepared in 2012 by the Member of the Mayoral Committee (MMC) for Planning, which offered the Mayor a 'Mayoral Clean Sweep Inner City initiative' to address the many illegalities that characterise the inner city landscape, including 'illegal street trading' (CoJ, 2012). Whilst emphasising the need to address issues vigorously and in coordinated ways within the municipality, the proposal failed to identify municipal urban management shortcomings. ${ }^{18}$ Its strong emphasis on strict by-law enforcement led to the 2013 Operation Clean Sweep. The City's intention, stated in an internal report circulated to street trader organisations after the police intervention and before the court case, was to severely restrict the number of legal trading spaces (to 1500 legal trading spaces for the whole of the inner city $^{19}$ ) and to confine them into 'short streets' and 'linear markets' (CoJ, 2013). The plan was contested, and the matter eventually went to court.

The Constitutional Court's condemnation of Operation Clean Sweep put traders back in their trading sites and unleashed new dynamics within City institutions and politics. However it failed, at least in the short term, to significantly challenge the City's restrictive vision. The City, compelled to follow legislation, embarked on a formal process of Proclamation of Trading Restricted Areas and Designation of New Trading Areas in 2014 in which similar restrictive objectives, and assumptions that there are too many traders in the inner city, were guiding City official discourses (CoJ, 2014, 32.3). In this respect, the 1991 Businesses Act continues to remain a serious legal obstacle to the municipality's restrictive objective. The City has, from the late 1990s, consistently attempted to side-line or discredit the Act:

The creation of restricted and/or prohibited areas in terms of the Businesses Act [...] will entitle the SMLC to legally remove these traders from the affected areas. Although the Businesses Act advocates management through negotiation, practical experience indicates that unless one has large staffing resources the prevention of new traders into these areas is practically impossible. (GJMC, 1998)

While the requirements set out in the Business Act may by far be administratively cumbersome and possibly inconvenient, it is important to note that the Act makes no provision for an exemption there from or alternative for another, less cumbersome procedure to be followed. (CoJ, 2014: 32.9) (My emphases)

The policy currently developed by the City has, in this perspective, been reframed as a positive process of 'promulgating and designating trading areas in the inner city' (DED 2015): a strategic move to avoid falling under the Businesses Act, which focuses on conditions for 'prohibiting and restricting' trading spaces in the city.

The contrast between inclusive public rhetoric (the result of various participatory engagements and spearheaded by more progressive sections of the City), and the more internal policy guidelines, the technical details of by-laws consistently reiterating restrictive objectives (driven by other institutions in the City), is also reflected in the different positions

\footnotetext{
${ }^{18}$ It is interesting to note that this document was developed in parallel with the Inner City Road Map, a participatory process whose pro-poor and inclusive principles are in blatant contradiction with the Clean Sweep initiative (in spite of the Planning Department being involved in both processes).

${ }^{19}$ For 2700 registered traders at the time.
} 
of departments and agencies with respect to Operation Clean Sweep, which are not highlighted publically but are sometimes perceptible in interventions. The CSU and the City Manager are keener to reflect, engage and learn lessons from the case ${ }^{20}$, while the Johannesburg Development Agency (JDA), in charge of inner city redevelopment, is taking a pragmatic and progressive stance (JDA, 2013). The institutions directly linked to the governance of the informal economy - the Department of Economic Development (DED) and Metropolitan Trading Company (MTC) ${ }^{21}$ - were apparently opposed to the Operation, and are now focusing on damage control in its aftermath ${ }^{22}$. The tense context of the ongoing Constitutional Court case, and the crisis of the ANC (marred with scandals at the higher level of the state, weakened by increased factionalism and fearing electoral competition especially in large cities ${ }^{23}$ ) are not conducive to these internal debates reaching the public realm, and officials are in any case bound by their obligation of confidentiality.

\section{Framing Institutions to (Not) Govern Street Tradling?}

A way to deepen our understanding of the municipal policy goals over time, beyond the public policy documents framed by tumultuous participatory processes on the one hand, and those crafted in careful legal language (especially since the court case) on the other, is to look at how these policies (in their progressive rhetoric and their restrictive undercurrents) are articulated with the institutions constructed to govern and manage street trading.

These institutions can be categorized in three ways. First, it is important to locate street trading within the City administration: in a nebulous set of departments and agencies whose roles shift over time, coordinated by the Department of Economic Development (DED). Secondly, various spaces and platforms for engagement with trader groups have been set up, more or less formally, and whose scale, organization and functions in the governance of street trading need to be examined. Thirdly, the City has been silently delegating the management of street trading to the private sector, to City Improvement Districts (CIDs), where there has been experimentation with a mix of exclusionary and progressive models.

\subsection{Denialist formal institutions, in charge of street trading that should not exist}

Due to the restructuring of local government in the late 1990s, and the adoption of a costrecovery approach to sections of urban management (the iGoli $2002 \mathrm{Plan}^{24}$ ), the functions of governing street and market trading were split between a steering arm (the Department of Economic Development, DED) and what was supposed to be a financially self-sufficient operating municipal entity (The Metropolitan Trading Company, MTC). The latter is in charge of managing markets as well as selected transport facilities (including taxi ranks), a potentially lucrative but vastly informal constituency.

\footnotetext{
${ }^{20}$ As illustrated by its request for Wits University to explore the state of knowledge on informal economies for the City of Johannesburg, under the AFTRAX project (Dinath \& Zack, 2014).

${ }^{21}$ See section 3 of this paper.

${ }^{22}$ Some of the relevant officials took official leave during the Operation (personal conversation, 2015).

${ }^{23}$ In the August 2016 local government election the ANC lost in Johannesburg and a number of metropolitan municipalities to the main opposition party, the Democratic Alliance.

${ }^{24}$ See note 12 above.
} 
The Department of Economic Development (DED) has the responsibility of defining policy directions for street trading in the city. Amongst other, possibly more strategic, but more classic duties (for metropolitan economic development in the economic capital of the country), it has a unit dedicated to informal trading, developing policies and by-laws, plans and guidelines, and facilitating broad engagement with stakeholders. It also undertakes the task of identifying and demarcating trading spaces in the city. However, informal trading is seldom mentioned in DED strategic documents, and most documents pertaining to street trading are not accessible on its website. One also needs to mention the personalization of power in the City, with one DED official in charge of street trading since the early 2000s having built multiple networks and acquired a deep understanding of the sectors' dynamics, however often acting as a gatekeeper through sparingly and opaquely distributing the knowledge he has accumulated, possibly due in part to the difficult position he finds himself in, embodying the municipal contradictions between inclusive rhetoric and restrictive practices towards street trading.

Governing inner city street trading involves other City departments (Planning, Transportation, Metropolitan Police), administrations (Region F covering the inner city) and municipal entities (JDA, for investment in inner city infrastructure; and MTC, for the management of markets ${ }^{25}$ ). However their relation with DED is not formally defined, and shifts according to political contexts. One can however decipher four key relationships (see Figure 1). Two are constant and part of the governance model, formally or not. The first is the coordination with MTC: a close but unclear programme of joint work since the early 2000s, where MTC used to report to DED or to its political head. A second close relationship is between the DED and the Johannesburg Metropolitan Police Department (JMPD) - where DED has no formal authority over JMPD but the municipal police, tasked with traffic regulation but also tracking by-law infringements, remains a key element of the street trading management ${ }^{26}$ model (see below).

\footnotetext{
${ }^{25} \mathrm{Cf}$. Annexure for the list of acronyms.

${ }^{26}$ The government of street trading is exclusively referred to, in municipal language, as street trading 'management' - a nuisance in the inner cityscape, that needs to be 'managed' to mitigate its assumed negative effects.
} 


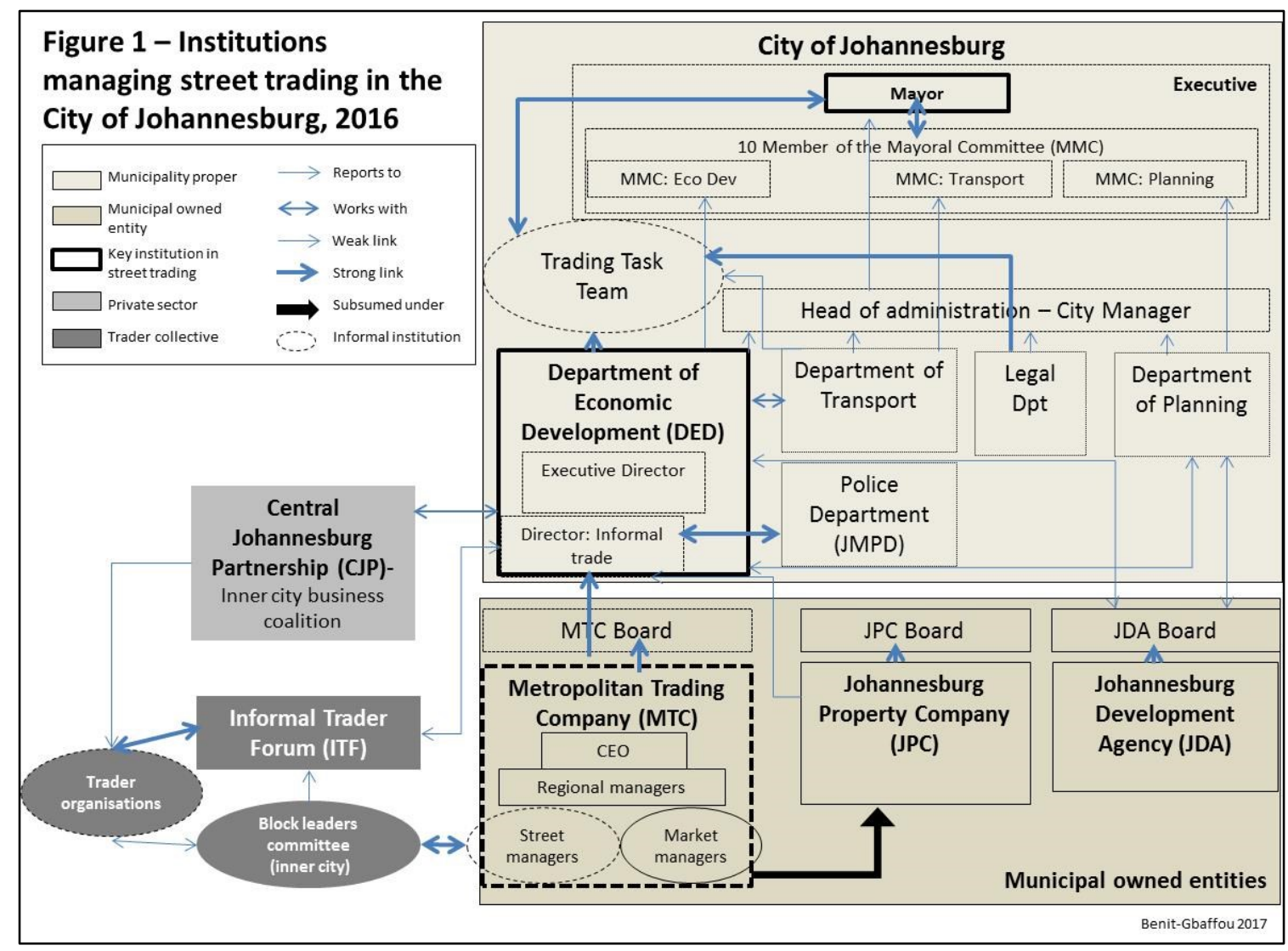

Two inter-departmental links have developed recently in response to policy and political shifts: with the Transport Department, which has become more powerful under Mayor Tau ${ }^{27}$; and with the Legal Department, after the debacle of the Constitutional Court judgment (where the City lost, had to backtrack and was publically humiliated by the judge for degrading treatment to traders). After the judgement, the Mayor instituted an interdepartmental operational Trading Task Team to govern the sector - with DED playing a leading role, together with the Legal Department. The effect is that an ad hoc and opaque institution now governs the sector, based on legal caution, and the City Manager was effectively side-lined in the issue.

\section{Metropolitan Trading Company (MTC): ill-adapted mandate, informalising institution}

The mandate of the MTC, created in 1999, is to 'manage informal trading markets and public transport facilities in the City of Johannesburg' (MTC 2005). Its aim is therefore explicitly property development and management, the provision and maintenance of trading and transport infrastructure within specific off street facilities. Its mandate does not include the regulation and development of traders, or the maintenance, infrastructure provision and management of sidewalks. The 2007 Informal Trading Policy was more precise in this respect, mentioning within MTC's mandate the allocation of trading sites, management of lease agreement and trading rentals fees, the issuing of smart cards to traders and registering

\footnotetext{
${ }^{27}$ The Mayor's flagship project, the Corridors of Freedom, is based on a rapid bus network linking former townships to places of economic opportunities. He has been driving this project with and though an empowered and resourced Transport Department in the City.
} 
all traders in a computerized database (CoJ 2007: 9). However, the policy remained unclear as to how this was to be articulated with trading sites demarcation by the DED (CoJ 2007: 8). In spite of this new 2007 policy specification, MTC's official mandate did not change, still explicitly focused on market and taxi ranks management (MTC 2012).

This ill-adapted focus has been aggravated by the transfer in 2013 of MTC's assets and functions to the Johannesburg Property Company (JPC), due to a number of issues ranging from a lack of financial sustainability ${ }^{28}$ to allegations of corruption. This transfer of street trading management to JPC, rather than its more functionally logical integration into DED, was decided by the Mayor, confirming the centrality of asset-management to his view of street trading government, rather than a developmental, people- or street-oriented approach. JPC is not developing clear strategies, business plans nor tools to operationalise the street trading policy - more marginal in its sector of intervention than it was even for MTC (JPC, 2015). The defined mandate of MTC and JPC around markets remains based on the ongoing assumption that street traders will all be relocated into markets - that they should not exist and will soon not exist. This could be termed the denialist dimension of street trading government.

In practice, MTC (and later JPC) constantly had to face the reality of the existence of street traders and the need for their (minimal) management: hence the development of unwritten practices and functions within the institution - and arguably even informal institutions. MTC market managers, and inner city street officials, are some of the MTC officials encountered by traders but not mentioned in any organogram (MTC 2012) or public document. Street officials used to play a key role in engaging with traders at a street level, and informally managing an unofficial street trading waiting list (Author 2014, Khwashaba 2015) - a space for petty corruption possibly, but also, simultaneously, a highly decentralised, flexible and problemsolving form of area-based management.

\section{The Metro Police, a key institution to manage (repress) street traders}

The third municipal entity in charge of street trading and, as traders would say, the foremost, is the JMPD. The direct consequence of the City's approach to street trading - restrictive in its policy objectives, denialist in its institutional choices - is the criminalization ('illegalization') of the majority of street traders. The fact that the majority of street traders in the inner city are rendered illegal, combined with an absence of dedicated street management institutions, leads to the prominence of policing as a way to manage street trading.

This distracts public resources away from other, more developmental, needs of the sector; it also leads officials and the public to equate failure of management with failure of enforcement. The business sector keeps calling for a better application of existing by-laws ${ }^{29}$; traders denounce police corruption as the main factor of failed management ${ }^{30}$; and City officials keep promising 'strong management' (meaning strong enforcement) as their key

\footnotetext{
${ }^{28}$ Partly due to the taxi associations' refusal to pay rent (Pernegger 2016), and traders unequal (and declining) acceptance to do so.

${ }^{29}$ See CJP submission in the Constitutional Court case (CJP 2014).

${ }^{30}$ CUBES trader organisations workshop, Johannesburg, 25.09.2014. See also Clark, 2014.
} 
response to management failures ${ }^{31}$. Meanwhile, traders do not stop denouncing municipal police abuse - harassment, brutality, illegal confiscation of goods (without receipt or proper procedure), and widespread corruption (Clark 2014).

JMPD officers are the main face of the state that traders encounter on an everyday basis. Their behavior varies - between tolerance and laissez faire, explicit or implicit request for bribes, and brutal repression, confiscation of goods or physical violence - alongside political cycles where voter support, the need to demonstrate the state's efficient intervention, and the branding of urban orderliness, are priorities. This however does not depart from internationally documented practice (Anjaria 2011, Kamete 2013) and might not even be specific to street trading: except that in this case, alternative institutions (such as DED and MTC) are perhaps particularly ill-adapted and dysfunctional, leaving a gap that is filled by policing interventions.

\subsection{Spaces of engagement with trader collectives: everyday problem-solving, but opaque and un-strategic}

Yet municipal institutions are not the only ones to define how street trading is governed. Several spaces of engagement between the municipality and trader leadership, have emerged and gained a level of institutionalisation.

The development of spaces of engagement between municipal officials (mainly from DED and MTC-JPC) and trader collectives is in line with international trends towards more participatory governance (Cornwall 2008), appropriated locally through South African postapartheid commitment to deepening local democracy (Heller 2011). This participatory wave is often entangled with neoliberalising trends (Miraftab 2007) and has sometimes been viewed as a form of manipulation of traders into accepting policies that counter their interests (Morange 2015b). However we posit, following Auyero (1999), that 'clients' are never the dupes of their patrons, and although in a structural position of domination, find benefits in these compromises. The development of spaces of engagement, that can be read as institutions with their rules, rituals and norms, also corresponds to the increasing adoption of interactive policy instruments in the age of urban governance (Linder \& Peters 1989), complementing more coercive approaches.

In the case of informal trading in Johannesburg, these participatory institutions are two-fold. The Informal Traders Forum (ITF) set up in 2010 through official terms of reference (even though these are hardly followed) is meant to set up:

a formal informal sector collective representative body of all informal business formations in Johannesburg to engage with the City, serve as an institutionally recognised informal business voice for informal traders within the City, and serve to provide as an oversight and advisory mechanism towards the successful implementation of the Informal Trading Policy and By-law (DED 2010, my emphasis).

The ITF (suspended since Operation Clean Sweep) was used as a space of informationsharing (DED presenting new developments in the City to traders) and problem-solving,

\footnotetext{
${ }^{31}$ CoJ consultation process: Inner City Promulgation and Designation of Trading Areas, Johannesburg, 29 July to 6 August 2014.
} 
where trader leadership would raise specific issues. It was criticised by trader leaders as a space of division, clientelism, limited accountability and minimal strategic power. However, the Forum served an important information and networking function, both with the DED official and between trader organisations. ${ }^{32}$

A second, less formal institution for engagement is the Block Leaders Committee, organised and convened by MTC, and covering sections of the inner city. Formed by trader leaders elected at a block level under the auspices of DED (whose legitimacy was therefore often contested by more autonomous street trader organisations: Author 2016), the Committee met monthly with MTC to collectively solve local operational and practical issues. Not mentioned by any policy or institutional document, but framed by internal house rules (Khwashaba 2015), this inner city committee played important regulatory functions, as evidenced by trader leaders' complaints over its termination (together with the ITF) in the aftermath of Operation Clean Sweep; and the City's intention to reinstate such institutions when the legal battle has subsided.

\subsection{A delegation by stealth to the private sector}

Somehow disconnected from these municipal and participatory institutions, a third type of institution for the management of street trading has, silently and incrementally, emerged. It is generally understated or overlooked that about half of the authorized street traders in inner city Johannesburg are directly managed by the $\mathrm{CJP}^{33}$ in the inner city CIDs. About 1300 traders in the inner city are not managed by MTC, but are registered in a separate CJP database $^{34}$ and managed by its private company, coordinating the extra security and cleaning services needed in trading spaces, in specific pockets of the inner city, funded through the ring-fenced, area-based CID levy on property owners.

A possible explanation for this delegation is the fact that it is legally difficult for the municipality to raise a dedicated, ring-fenced tax to resource inner city management ${ }^{35}$ : this constraint might explain the political tolerance and even possible tacit encouragement of CIDs, as at least one way of levying inner city property owners and having such levy spent locally. A complementary explanation is that this delegation is the pragmatic response to the City's denialist approach - if public institutions are framed as though street traders did not exist, a way to deal with existing street traders without questioning the policy and institutional instruments, is to delegate it to a third party.

This delegation, called 'partnership' by the City and the CJP, took the form of several temporary Memoranda of Understanding and a Joint Venture (JV), signed between the CJP and EDU/DED or MTC in the mid 2000s. The $2005 \mathrm{JV}$ established the joint management of

\footnotetext{
${ }^{32}$ If one judges it by the eagerness of trader leaders to attend these meetings, in spite of them being irregular, always announced in a rush, and without an agenda nor minutes.

${ }^{33}$ See note 16 above.

${ }^{34}$ In 2014 DED announced that there were 2700 registered street traders in total (on both MTC and CJP databases). The CJP database apparently includes 1000 to 1300 street traders (depending on the source).

${ }^{35}$ In reaction against the apartheid fragmentation of racially defined municipalities with unequal tax bases, postapartheid legislation explicitly restricted the ability of (integrated) municipalities to ring-fence budget towards specific areas - especially operational budgets, which are needed for urban management.
} 
street traders in two inner city CIDs: the cost of this management for CJP was supposed to be covered by traders' rents, paid into the JV account. However, due to the erratic collection of traders' rents, CJP eventually claimed direct financial compensation from the City (to no avail). The agreement was not renewed from 2008 onwards, however CJP pragmatically (but therefore informally, for no immediate financial gain, with no mandate and less legitimacy) continued to manage street traders in the two CIDs.

One could talk about a 'privatization by stealth', of an 'informal delegation' of street trading management to the private sector. Besides the fact that the agreement has not been renewed (but CJP continues to manage half of the authorized traders in the inner city), one is struck by the opacity surrounding these agreements: the partnership or delegation were never presented as an idea, a model, or even as a pilot in any public or policy debates; nor was it mentioned in public documents. Clearly any form of privatization of urban governance in Johannesburg is politically sensitive, in particular after the contests around iGoli $2002^{36}$.

This informal delegation however increased confusion around roles and responsibilities in street trading management, contributing to the difficulty of collecting rent from traders - as CJP then lacked the legitimacy to enforce it. It also fed conflicting public perceptions, opposing 'well governed private areas' to 'failed public management' in non CID areas: a perception true to some extent, given the management resources mobilized by the private sector in the two CIDs tolerating street trading. This fragmented view consolidated the status quo of a majority of inner city CIDs prohibiting street trading, with limited public awareness of the systemic impact that such prohibition has for street trading in the inner city as a whole, and publicly managed parts of the city in particular.

However, the practical experience of private management of street trading at a precinct level in selected CIDs has consolidated a relatively progressive and innovative management model (where traders enjoy some security of tenure and dedicated management services), as well as fostered a paradoxical alliance between one street trader organisation and the CJP (Author 2015). The ambiguous position of CJP (accepting and managing street traders in limited spaces, prohibiting them in general, and supporting the City's efforts to push traders into markets and remove them from the sidewalks) has not led to shifts in the restrictive municipal approach.

\section{Policy Tools: Reflecting the Complexity of an Intractable Problem, or Resulting from a Politics of Un-Mapping?}

Articulated to policy documents and institutions, more technical tools are elaborated to govern street trading in Johannesburg, further shedding light on the City's objectives. This section examines a few that are consistently used or avoided: 'the market' as the constant (yet contested and inefficient) spatial fix for street trading management since the late 1990s; permit, licenses, lease agreements and smart cards, whose multilayered and confusing coexistence persists over time; and key tools that are not used (in what could be called a 'politics of un-mapping': Roy 2009): traders census and a trading spatial plan.

\footnotetext{
${ }^{36}$ See note 11 above.
} 


\subsection{Markets as 'the' solution to street trading management}

Since the late 1990s, markets have been considered by City institutions (and by the private sector) as the key solution to issues of street trading management: the only way to govern street traders was to relocate them into markets. This policy has been proactively pursued in the early 2000s, with the construction of new markets concurrent to the banning of street trading at a neighborhood level, and attempted relocation of traders therein. It has generally led to the reoccupation of streets by now illegalized traders, perceived by market traders (some of which forcibly removed from the streets) as unfair competition.

Nevertheless, 15 years later, the City's instruments for street trading management still bring 'the market' as the tool par excellence which will solve the street trading management crisis. The tool itself has evolved, from large malls to more 'informal', smaller neighborhood markets (where the rent is kept minimal); to the invention of 'linear markets' (pedestrianised, short streets with covered stalls), as defined in the 2007 policy; to refurbished 'buildings' possibly inspired by the dynamic ethnic trade entrepreneurship in the inner city's Ethiopian quarter (Zack 2014). It is worth noting the effort at accommodating a greater variety of informal trading forms, in response to traders' critiques and resistance: the idea of 'linear market' is an attempt to build on passing pedestrian flux, and the initial MTC project aimed at providing sufficient number of trading sites to accommodate most existing traders (Muhle Unlimited Designs 2008). However, in practice, linear markets were implemented together with the drastic reduction of the number of authorized trading sites. The policy intention has therefore not really shifted from limiting sidewalk trading, and relocating traders into various forms of market trading, in spite of innovations.

It is not that City officials are unaware of the international evidence, national alternative practices, and local resistance by street traders to relocation into markets or buildings arguing that street trading is a different type of trading practice, 'purchasing on impulse rather than on purpose', to use one street trader leader's vivid articulation. A 2005 EDU internal document does recognize the limitation of markets as a full alternative to street trade:

While markets do play a role in the formalization of trading activity, they specifically don't address the needs of survivalist traders who survive on passing pedestrian trade impulse purchases - mostly for food items. [...] While it might be an option to create markets for non-impulse purchase (clothing, shoes, haircuts, street mechanics, handbags, radios, cellphones) it is not viable to move impulse purchase traders out of the pedestrian traffic. Doing so will simply create a vacuum that other traders will fill unless enforcement is implemented continuously. (EDU 2005: 3; 4).

However, the same document recommends

$[\ldots]$ the proactive migration of all street traders into markets (offering different formats) [...], if well planned such that it is seen as a good business opportunity. Conversely it may simply exacerbate the problem as it creates opportunities for new informal traders to enter the streets. (EDU 2005: 9).

One could follow up occurrences of the 'market as key tool' idea throughout all municipal documents available since 2000 - especially internal, non-public documents. The vision imagined by Operation Clean Sweep was for instance to severely restrict trading sites and relocate them into markets, including 'linear markets' and 'short pedestrianised streets' (CoJ 
2013). The post Operation Clean Sweep draft informal trading plan, although stating its 'paradigm shift' towards increasing authorised trading spaces in the inner city, still plans to do so primarily by relocating street traders into more markets, buildings and (limited) linear markets (DED 2016).

The stubbornness of this vision of the 'market' as the miracle tool to solve street trading management issues, in spite of its contestations and inefficiencies, is difficult to understand, but one could trace a number of complementary hypotheses. First, the 'garbage can' theory of decision-making applies: decisions are taken not according to what is needed to resolve the issue, but to the instruments (institutions and tools) that are already available (Cohen et al 1972). MTC-JPC remain geared towards developing and managing markets. Capital investment is more easily available (to develop markets) than operational budget (to set up a bureaucratic structure, and possibly area-based management systems to efficiently manage the streets). Finally the market remains an easier object to build, contain traders, manage land uses conflicts, provide infrastructure and collect and manage traders' rental payments. Even if more innovative solutions of on-street trading management have been experimented (in the CID model, but also by small groups of traders: Author 2014), they require a more robust reform of institutions.

A second explanation of the resilience of markets as a solution to street trading management, is that traders themselves have ambiguous positions towards City's investment into markets. As mentioned by some trader leaders, 'nobody wants to remain in the street forever'. Getting access to a stall in a market or building is often perceived as providing greater security of tenure and imagined as the next step in an individual business path; getting contracts as organisations to manage market places or buildings (as this is being set up in four existing markets in Johannesburg) provides an additional incentive. Therefore, the City's proposals for the development of markets and buildings suit certain constituencies, even if relocation (when it happens) is resisted by many traders, and sidewalk trading remains the irreplaceable entry point for low capital traders into the informal trading economy.

\subsection{Permits, licenses, leases, smart cards, etc.}

Confusion also exists around what makes a trader 'legal' in the inner city streets. Its persistence over time reveals that there is more to it than a practical challenge: a lack of political will to clarify matters, and the likely convergence of various interests in keeping the matter muddled. This situation echoes the well-documented confusing layering of multiple informal settlements status, denominations and rights experienced in Indian cities, explained by the historical legacy of multiple governance processes (Benjamin 2004). This blurring constitutes a key obstacle to the governability of Indian cities (Roy 2009, Heller 2015).

In Johannesburg there are a multiplicity of formal documents that a trader might use to demonstrate authorization: smart cards (introduced since 2009 but not rolled out systematically), older trading permits, trading site lease agreement, and rent payment invoices (Clark 2014). Registered traders (with or without smart cards) might have or not have a demarcated trading site. Some traders have a lease agreement (i.e. a demarcated trading site) and are paying MTC, but do not have smart cards. Some do pay rent to MTC but have no 
lease to show, and rely on MTC payment receipts to demonstrate their authorization to trade. For the many traders managed by the CJP, it is unclear what type of document they are provided with to assert their legal status. Most have ceased to pay rent, which the CJP in any case no longer legitimately claims, since its mandate to manage street trading has formally expired.

No policy document (policy, by-law or guideline) exists to clarify the situation and enumerate the existing status of traders. The smart card system announced in the 2007 policy was supposed to unify the authorization process and documents; however the 2009 by-laws added to the confusion, mentioning lease agreements and 'a token' given to authorized traders by the City, however ignoring smart cards and the variety of trading permits and licenses that were mentioned, but not defined nor systematically listed, in the 2007 Policy.

This opacity could be attributed to municipal lack of capacity: the complex nature of the problem, a level of technical incompetence, or lack of resources. One of the issues rests with the fact that the two key processes (trading rights and trading site allocation) are disconnected. For instance, MTC aimed at providing 4000 smart cards to inner-city traders by mid-2010 (MTC 2010), but during that time the number of trading spaces demarcated by DED was extremely limited: in 2013 only 800 demarcated trading sites had been allocated for the 2700 registered inner city traders and the 7000 odd existing traders (JDA 2013). The universal complexities faced by cities in undertaing planning for street trading (based on the difference between the registration of traders, as recognition of their right to trade; and the licensing of traders, as allocation of a specific trading site), can, when not clarified in anyway by official guidelines, directly fuel opportunities for corrupt practices. A black market of trading sites can fester, which further disconnects the authorised traders' database from realities.

This disconnect was arguably one of the motivations for Operation Clean Sweep in 2013. Some City officials indeed argued that the municipality was utterly unable to know who was trading where, who was 'legal' and 'illegal' in the inner city. Their version blamed this uncertainty on corrupt deals and on the ungovernability of traders, instead of linking it to the structural consequences of their own policies. After the police brutally evicted all traders from the inner city, officials worked towards rebuilding the database. This appeared to be based on an objective of further restricting the numbers of traders and reallocating trading rights to selected traders, through 'verifying' which traders had a 'real' right to trade as a condition for their return to their trading space ${ }^{37}$. Operation Clean Sweep can be seen as a way for City officials to attempt to regain control over street trading. The desire to create a blank slate from which to start afresh can be understood as the result of the powerlessness of City officials in charge of managing street trading that they have themselves construed as non-existent. The municipal inability to register existing street traders might be linked partly to the fluidity of the sector itself; but, we have argued (Author forthcoming), has also been structurally manufactured by the City itself.

\footnotetext{
${ }^{37}$ The verification process was also a way for officials to cancel the trading permits allocated to foreign traders, calling the Department of Home Affairs to check their status in the country, or re-attributing their stall or their smart card to (loyal) South African traders (Author, 2014).
} 


\subsection{Traders' numbers \& spatial development strategy: non-tools for governing street trade}

In parallel to the attempted creation of a database of authorized traders through smart cards, what is striking is the absence of an up-to-date census of existing traders and their localization in the inner city. The latest officially published figures are from 2001, where about 10000 traders were counted in the inner city (CoJ undated). In 2008 a census was conducted by the DED-MTC for inner city traders, however inaccessible to the public ${ }^{38}$. Stakeholders (academics, business and traders alike) in several rounds of participatory processes on street trading governance have called for a census, to no avail - officials' responses were that they were sticking to the number of 'legal traders' (2700) as the traders they would consider in their plan, arguing the (undefined) rest should be dealt with through law enforcement. Meanwhile, official documents and discourses keep referring to limited or exceeded street 'carrying capacity' to accommodate traders:

A major problem of the sector relates to the sheer number of informal traders. There are an estimated 10
000 traders in the inner city and only about $10 \%$ of these can be accommodated in markets. It is clear that
the sector cannot accommodate all the traders. [...] It is also clear that there is a limit to the number of
traders the streets can accommodate. (CoJ undated, probably 2001).

It has become clear that the City's approach of designating an increasing number of trading areas have resulted in the carrying capacity of the urban environment in the Inner city being exceeded. (CoJ 2014, 32.3).

Our aim is to provide a technical, scientific plan to accommodate street traders. But the inner city has a limited number of trading sites: we have to work with it. (Public statement, DED official, City of Johannesburg consultation process, 6 August 2014: emphases mine).

This battle of numbers is intrinsically linked to issues of spatialisation of existing trading spaces. While official numbers have not been available since 2001, the mapping of existing or authorized trading areas and sites was also non-existent for a long time. The 2016 development of a spatial trading plan by DED is a new practice (DED 2016) which can be understood as a way for the City to respond to the court case and escape the requirements of the 1991 Businesses Act (as mentioned earlier), by designating and demarcating authorized trading areas (rather than prohibiting and restricting spaces open to trading) through a spatial plan. This spatial strategy is however still not based on numbers and location of existing traders, nor on spatialised numbers for the trading sites' intended provision. It does not reopen the debate on vast inner city spaces prohibited to trading (in particular the majority of CIDs). It consolidates as a fait accompli the provision of limited trading spaces in confined areas in the city, without questioning the broader (restrictive) spatial and economic strategy inspiring the plan.

Interestingly, the need for a spatial development framework for street trading was stressed in the 2007 Informal Trading Policy (CoJ 2007: 6), pushing for an increased role for the Department of Planning, that was explicitly asked to make provisions, in any new urban developments, for sufficient space for pedestrian, vehicular mobility and street trade. This role

\footnotetext{
${ }^{38}$ A consultants' report for MTC (Muhle 2008) mentions a baseline survey of informal traders conducted for MTC, which estimates the number of street traders in the inner city at about 7000 in 2008 . This figure has however never been released in public documents or engagements.
} 
has not been followed by any instrument or tool, and does not seem to have altered practices, where the Planning Department is conspicuously absent from street trading governance in spite of the issue being essentially linked to competing land uses. In the 2016 spatial planning process to define the trading plan for the inner city, it is rather the Transport Department, and its engineering consulting firms, which were called upon by DED to give their 'expert' input: this has helped DED once again legitimize an extremely restrictive approach to street trading, seen as hampering mobility in the city ${ }^{39}$.

Why this 'will not to know' by state authorities? Roy frames the concept of a 'politics of unmapping' (2009), where public authorities deliberately produce zones of opacity and uncertainty in order to keep flexibility in how they deal with future urban development. Keeping numbers unknown (numbers of existing traders, numbers of trading sites to be provided, in the inner city overall and at precinct or street level) might be only partly intentional: enumerating mobile traders is challenging (Roever 2011), as is defining (technically and politically) acceptable numbers of trading sites per area. But opacity around numbers is used by City officials in many ways, and therefore the incentive to increase knowledge on the sector to craft adapted policies is low. Not providing numbers of trading sites, in contrast to (unknown) numbers of existing traders, serves as a shield for officials to disguise the strongly restrictive approach to street trading: it helps sticking to the public rhetoric of provision and care for the poor, whilst limiting public contestations over underprovision. Not mapping the number of sites per area assists in avoiding key public debates on local criteria for decisions but also overall spatial strategy for the inner city: it is helping not to reopen a debate on prohibited trading spaces, in particular in CIDs that are covering vast portions of the inner city. The City thus remains free to act in unilateral ways in the name of 'technical decisions' that no member of the public can assess - the arbitrary nature of which has been reflected by the fluidity of the 'maximum' number of trading sites the City announces it 'can' cope with - ranging from 2700 prior to Operation Clean Sweep, 1500 during the Operation (CoJ 2013), to 4500 in its aftermath (DED 2016).

\section{Conclusion: The vicious cycle of street trading mismanagement and the public production of scarcity}

Through the study of inter-related policy instruments, this paper has painted a picture of the state choosing not to govern street trading. Rather it manages it, by sedating the most visible opposition through a progressive public rhetoric masking its real political choices, and a degree of opacity and blurredness of its institutions, recourses and interventions. Progressive but toothless strategic documents indeed mask the reality of other, more powerful internal instruments, not accessible to the public and geared towards the continuous restriction of street trading in the inner city. These internal policy instruments consist of restrictive internal policy guidelines instructing relevant officials; denialist institutions aimed at managing market infrastructures rather than streets and people, and their correlative over-reliance on by-

\footnotetext{
${ }^{39}$ There was much chaos in the room when one junior engineering consultant, presenting the Transport view on the trading plan to an audience of traders, insisted that from a technical point of view, no trading should be allowed on sidewalks narrower than 5 metres (DED workshop, 2015, May 19) as there are almost no such sidewalks in the inner city!
} 
law enforcements fueling dynamics of corruption, patronage and state violence (all the more confused that what constitutes 'legality' for a street trader is often unclear); delegation by stealth to the private sector, de facto but informally managing half of the legal trading population in the inner city; and a politics of un-mapping and un-numbering, deliberate ignorance and opacity on the nature of 'the issue' so that the state avoids taking responsibility for the welfare and livelihoods of the traders it criminalizes. The contradiction between a relatively progressive public rhetoric, and a set of other policy instruments consistent in their restrictive objectives, is, if not initially intentional, actually functional in preventing or sedating public debates around the issue. But it also deprives the City of the ability to reform and to fix what is actually a vicious cycle of mismanagement and oppression, that Operation Clean Sweep was a logical conclusion as well as a manifestation of.

What is the relevance of the Johannesburg case for governing street trading elsewhere, and in particular in other cities of the global South? The paper makes a theoretical argument - that in spite of the complexities of the government of street trading in large metropolitan areas, there are actual policy and technical choices that officials make. These choices are often largely obscured by public rhetoric and even to some extent public participatory processes, and by the opacity of institutional arrangements, technical tools and minute decisions that largely are shielded from public gaze. The paper warns against taking public documents at face value, considering them rather the 'tip of the iceberg', and illuminates some of the more powerful policy instruments, that are more accurately defining state objectives but remain outside of the public realm (that I was exposed to thanks to a long exposure and engagement in actionresearch). These other policy instruments (beyond the public documents) are by no means unique to the case of Johannesburg: the paper illuminates how important it is for academics, activists and citizens in other cities to interrogate those other instruments in the field of street trading governance. In particular, the politics of numbers (of existing traders versus authorized traders) and mapping (location of trading sites) is often a blind spot of existing research on street trading governance, or negotiations by trader organisations themselves. More broadly, the paper opens to the idea that street trading is not in itself ungovernable. A paradigm shift, similar to the one that has emerged in the field of informal settlements, has not yet occurred: accepting street trading as a feature of developing cities, as a popular response to contexts of mass unemployment that needs to be accommodated and regulated in interaction with other street functions and uses. By identifying municipal choices, the paper opens a reflection on alternative governing goals and instruments. It emphasizes the importance of a politics of number (registration of all traders, based on existing needs and uses, to be accommodated), and a related politics of mapping (negotiating, designing and managing trading spaces). It elevates the question of competing land uses, in governing street trading in dense inner cities of the South, in contrast to the usual purely economic thinking on the activity. It alerts to the much needed exploration of appropriate institutions and processes aiming at mitigating land use conflict, such as enhanced engagement, support to street trading organizational capacity, area-based design and management solutions.

\section{References}


Anjaria, S. 2011. 'Ordinary State: Everyday corruption and the politics of space in Mumbai'. American Ethnologist 38(1): 58-72.

Author forthcoming

Author 2016

Author, 2015

Author, 2014

Auyero, J. 1999. ' 'From the clients' point of view: How Poor People Perceive and Evaluate Political Clientelism'. Theory and Society 28(2): 297-334.

Bayart, J.-F. S. Ellis, and B. Hibou. 1999. The Criminalisation of the State in Africa. Bloomington, Indiana: Indiana University Press.

Bayat, A. 1997. 'Uncivil society: the politics of 'informal people',. Third World Quarterly 18(1): 53-72.

Benjamin, S. 2004. 'Urban land transformation for pro-poor economies'. Geoforum 35(2): 177-187.

Bromley, R. 2002. 'Street Vending and Public Policy: A Global Review. International Journal of Sociology and Social Policy 20(1): 1-29.

Clark, M. 2014. Informal Trade in Inner-City Johannesburg: Scoping Study. Draft report, prepared for the Socio Economic Rights Institute (SERI), Johannesburg.

Cohen, M., J. March, and J. Olsen. 1972. 'A Garbage Can Model of Organizational Choice'. Administrative Science Quarterly 17(1): 1-25.

David, S., O. Ulrich, S. Zelezeck and N. Majoe. 2013. Managing informality: Local government practices and approaches towards the informal economy - Learning examples from five African countries. Report prepared for South African Local Economic Development Network and South African Local Government Association, South Africa.

De Soto, H. 2000. The Mystery of Capital: Why Capitalism Triumphs in the West and Fails Everywhere Else. London: Black Swan.

Dimas, H. 2008. Street Vendors: Urban Problem and Economic Potential, Working Paper in Economics and Development Studies, Department of Economics. Bandung, Indonesia, Padjadjaran University.

Dinath, Y. and T. Zack. 2014. 'Explaining the Impasse: Why informal economic activity has not been consistently supported by the City'. In Zack, T., Charlton, S., Harrison, P. \& Jenkins, P. (eds), Alternative Formalities, Transnationalism and Xenophobia in the Inner City of Johannesburg (AFTRAX). Report prepared by the School of Architecture and Planning, Wits University, for the City of Johannesburg.

Grest, J. 2012. Statutory Representational Systems at Local Government Level: Ahmedabad, India. Report for StreetNet International. http://www.ilo.org/wcmsp5/groups/public/---asia/---ro-bangkok/documents/publication/ wcms_bk_pb_119_en.pdf

Heller, P. 2015. 'The Exclusion Field: Politics, Institutions and Inequality in an Indian City'. Working Paper, Brown University, Austin.

Heller, P. 2012. Binding the state: State capacity and civil society in India. Paper presented at the international workshop 'The Politics of Mediation', Collaboration for Research on Democracy (CORD), New Delhi, 10-14 December.

Horn P. 2014. Collective Bargaining in the Informal Economy - Street Vendors. EThekwini: report for WIEGO.

Hood, C. (2007). Intellectual Obsolescence and Intellectual Makeovers: Reflections on the Tools of Government after Two Decades. Governance: An International Journal of Policy, Administration, and Institutions, 20(1), 127-144.

Huchzermeyer M. 2011. Cities with 'Slums': From Informal Settlement Eradication to a Right To The City In Africa. Cape Town: UCT Press.

Kamete, A.Y. 2013. 'On handling urban informality in southern Africa'. Geografiska Annaler: Series B, Human Geography 95(1): 17-31.

Khwashaba, M. 2015. Street trade block leaders and the governance of street trading in inner city Johannesburg. Honours diss., Urban and Regional Planning. Johannesburg: School of Architecture and Planning, Wits University.

Kusakabe, K. 2006. Policy issues of Street Vending: An overview of studies in Thailand, Cambodia, Mongolia. Bangkok: Report for the International Labour Organisation. http://www.ilo.org/wcmsp5/groups/public/---asia/--ro-bangkok/documents/publication/wcms_bk_pb_119_en.pdf 
Kumar, R. 2012. 'The Regularization of Street Vending in Bhubaneshwar, India: A Policy Model'. WIEGO Policy Brief (Urban Policies), 7. http://wiego.org/sites/wiego.org/files/publications/files/Kumar_WIEGO_PB7. pdf

Lande, K. 2014, A Search for progressive street trading management model: understanding the principles of the Park Station Street Trading Management model. Honours diss., Urban and Regional Planning. Johannesburg: School of Architecture and Planning, Wits University.

Lascoumes P. \& Le Gales P. 2007. Introduction: Understanding Public Policy through Its Instruments-From the Nature of Instruments to the Sociology of Public Policy Instrumentation. Governance, 20: 1-21.

Lindell, I. ed. 2010. Africa's informal workers- Collective agency, alliances and transnational organizing in urban Africa. New York: Zed Books.

Lindell, I. 2008. The Multiple Sites of Urban Governance: Insights from an African City. Urban Studies. 45(9), 1879-1901.

Lindell, I. and J. Appellblad. 2009. 'Disabling governance: Privatisation of City markets and implications for vendors associations in Kampala, Uganda'. Habitat International 33(4): 297-404.

Linder, S., \& Peters B. G. (1989). Implementation as a Guide to Policy Formulation: A Question of 'When' Rather Than 'Whether'. International Review of Administrative Sciences, 55(4), 631-652.

Lipietz, B. 2004. ' 'Muddling-through': urban regeneration in Johannesburg's inner city'. Presentation to the NAerus annual conference, Barcelona.

Lund, F. and C. Skinner. 2004. 'Integrating the informal economy in urban planning and governance. A case study of the process of policy development in Durban, South Africa'. International Development Planning Review 26(4): 431-456.

Lyons, M. and A. Brown. 2009. 'Legal Pluralism and Development: street trade and regulatory reform in Tanzania'. IDEAR Working Paper 6. London: London South Bank University.

Matjomane, M. 2016. The politics of street vending policy making and implementation: The case of Ahmedabad, India. PhD proposal, Urban and Regional Planning. Johannesburg: School of Architecture and Planning, Wits University.

Matjomane, M. 2013. Strategies Used by Informal Traders Organisation Leaders to Influence Informal Trading Policy and Implementation. Master diss., Urban Studies. Johannesburg: Wits University.

Mitullah, W. 2003. Street Vending in African Cities: A synthesis of empirical findings from Kenya, Cote d'Ivoire, Ghana, Zimbabwe, Uganda and South Africa. Background Paper for the 2005 World Development Report.

Morange, M. 2016. Néolibéralisation, pouvoir et mise en ordre de l'espace urbain. Unpublished report for Habilitation à Diriger des Recherches, vol. 1. Paris : University of Paris Ouest Nanterre La Défense.

Morange, M. 2015a. 'Street trade, neoliberalisation and the control of space: Nairobi's Central Business District in the era of entrepreneurial urbanism'. Journal of Eastern African Studies 9(2): 247-269.

Morange M. 2015b. 'Participation, neoliberal control and the voice of street traders in Cape Town: a Foucauldian perspective on 'invited spaces' '. In Popular Politics in South African Cities: Unpacking Community Participation, edited by C. Bénit-Gbaffou, 171-195. Pretoria: HSRC Press.

Ngom, M.C. 2002. Les marchés enjeux politiques et économiques dans la gestion communale : Cas de Pikine, Mémoire de maitrise, Dakar : UCAD.

Nnkya, T. 2006. 'An enabling framework? Governance and street trading in Dar es Salaam, Tanzania'. In Contested Space: Street Trading, Public Space, and Livelihoods in Developing Cities, edited by A. Brown, 7998. Cardiff: ITDG Publishing.

Perberdy, S. 2015. Informal sector enterprise and employment in Gauteng. GCRO Data Brief, 6. Johannesburg: Gauteng City Region Observatory (GCRO).

Pernegger, L. 2016. Unpacking 'informal' practices of the state: Three stories from the City of Johannesburg. Working Paper. Johannesburg: University of Witwatersrand, Centre for Urbanism and Built Environment, Practices of the State in Urban Governance programme.

Peters, B.G. 2000. Policy Instruments and Public Management: Bridging the Gaps? Journal of Public Administration Research and Theory, 10(1), 35-47.

Pezzano, A. 2016. ' 'Integration' or 'selective incorporation'? The modes of governance in informal trading policy in the inner city of Johannesburg'. The Journal of Development Studies 52( 4): 498-513.

Roever, S. 2011. 'How to Plan a Street Trader Census'. WIEGO Technical Brief (Urban Policies) 2. http://wiego.org/sites/wiego.org/files/publications/files/Roever_WIEGO_TB2.pdf 
Roever, S. 2006. Street Trade in Latin America: Demographic Trends, Legal Issues, and Vending Organizations in Six Cities. Report prepared for WIEGO Urban Policies Programme, October 6.

http://wiego.org/sites/wiego.org/files/publications/files/Roever-Street-Trade-Latin-Amer.pdf

Rogerson, C. 2009. Strategic review of local economic development in South Africa. Report commissioned by the Department of Planning and Local Government (DPLG) and Afrikaanse Handelsinstituut (AHI), Johannesburg.

Rogerson, C. 2007. 'Second economy' versus informal economy: A South African affair'. Geoforum 38 (6): 1053-1057

Rogerson, C. 2000. 'Emerging from Apartheid's Shadow: South Africa's Informal Economy'. Journal of International Affairs 53(2): 673-695.

Simone, A. 2004. 'People as infrastructure: Intersecting Fragments in Johannesburg'. Public Cultures 16(3): 407-429.

Sinha, S. and S. Roever. 2011. 'India's National Policy on Urban Street Vendors'. WIEGO Policy Brief (Urban Policies) 2. http://wiego.org/sites/wiego.org/files/publications/files/Sinha_WIEGO_PB2.pdf

Skinner, C. 2008. 'Street Trade in Africa: A Review'. WIEGO working paper 5. http://wiego.org/sites/ wiego.org/files/publications/files/Skinner_WIEGO_WP5.pdf

Skinner, C. 2000. 'Getting institutions right? Local government and street trading in four South African Cities'. Urban Forum 11(1): 49-71.

Skinner, C. and I. Valodia. 2006. Two economies: Mistaken idea. South African Labour Bulletin 30(4): 57-60.

Tissington, K. 2009. The business of survival: Informal Trading in Inner City Johannesburg. Report prepared for the Center for Applied Legal Studies (CALS), Johannesburg.

Vedung, E. (1998). Policy instruments: typologies and theories. In M.L. Bemelmans-Videc, R. Rist, \& E. Vedung, (Eds.), Carrots, Sticks, and Sermons: Policy Instruments and Their Evaluation (pp 21-58). New Brunswick and London: Transaction Publishers.

Wafer, A. 2011. Informality, Infrastructure and the State in post-apartheid Johannesburg. PhD diss., Geography. Johannesburg: Wits University.

Zack, T (2014) 'Jeppe - where low-end globalisation, ethnic entrepreneurialism and the arrival city meet'. Urban Forum 26(2): 131-150.

Zack, T., Charlton, S., Harrison, P. \& Jenkins, P. (eds), Alternative Formalities, Transnationalism and Xenophobia in the Inner City of Johannesburg (AFTRAX). Report prepared by the School of Architecture and Planning, Wits University, for the City of Johannesburg.

\section{Documents}

Constitutional Court of South Africa. 2014. South African Informal Traders Forum and Others vs City of Johannesburg and Others; South African National Traders and Retailers Alliance and others vs City of Johannesburg and Others [2014] ZACC8.

City of Johannesburg (CoJ). Undated, possibly 2001. 'The rise and rise of hawking in the inner city'. Official website, http://www.joburg.org.za/index.php?option=com_content\&task=view\&id=134\&..\#ixzz329ktlwvW, accessed 15 May 2014.

CoJ. 2004. City of Johannesburg Metropolitan Municipality Street Trading By-Laws. Published in Provincial Gazette extraordinary $n^{\circ} 179$, dated 21 May 2004 under Notice Number 833.

CoJ. 2005. Management of Informal Trading: Creation of Restricted and/or Prohibited Areas. Johannesburg City Council resolution, passed in November.

CoJ. 2006. Growth and Development Strategy.

CoJ. 2007 [promulgated 2009]. Informal Trading Policy for the City of Johannesburg.

CoJ. 2009. City of Johannesburg Metropolitan Municipality Informal Trading By-Laws. Published in Provincial Gazette extraordinary $n^{\circ} 66$, dated 14 March 2012 under Notice Number 328.

CoJ. 2010. Terms of Reference: The Johannesburg Informal Trading Forum. Leaflet produced by the Department of Economic Development, Johannesburg.

CoJ. 2012. Report on the Status on the Inner City (region F) and the proposed initiative and programme to address current challenges ('The Mayoral Clean Sweep'). Development Planning, section 79 report.

CoJ. 2013. Progress of the Inner City Informal Trading Task Team. Report circulated to the main street trader organisations, Office of the Chief Operational Officer, 12 November. 
CoJ. 2014. Proclamation of Trading Restricted Areas and Designation of New Trading Areas Council in Inner City Johannesburg. Council resolution passed 22.05.2014

Department of Economic Development (DED). 2015. Promulgation and Designation of Trading Areas: Progress Report. Powerpoint document presented for public comment, Johannesburg City Hall, 19 May.

DED. 2016. Inner City Informal Trading Draft Plan: Presentation to the Inner City Trading Sector. Powerpoint document presented for public comment, Johannesburg City Hall, 26 April.

Economic Development Unit (EDU). 2005. Street trading management and policy. Internal document, 06 December.

EDU. 2006. Economic Development Unit and Property Owners Session. Report on workshop held on the 13 June.

Greater Johannesburg Metropolitan Council (GJMC). 1998. Management of Informal Trading: Creation of Restricted and/or Prohibited areas. Report presented by the Urban Development Committee: Southern Metropolitan Local Council (SMLC), and voted in SMLC Council, June.

GJMC. 1999a. From the Street into Markets: Inner City Informal Trade Management Programme.

GJMC. 1999b. Declaration of Restricted Trading Areas in the Johannesburg Inner City. Council resolution passed end 1999.

GJMC. 2002. Joburg 2030: Johannesburg's Economic Development Strategy. Corporate Planning Unit, Johannesburg.

International Labour Organisation (ILO). 2013. The Informal Economy and Decent Work: a Policy Resource Guide. 4.b3 Street Vendors: Innovations in Regulatory Support. http://www.ilo.org/emppolicy/pubs/ WCMS_210451/lang--en/index.htm

Johannesburg Development Agency (JDA). 2013. Position Paper on the Inner City Transformation Roadmap Approach to Informal Trade and Markets. Paper presented to the Department of Development Planning, 11 November.

Johannesburg Property Company (JPC). 2015. Integrated Annual Report 2014-2015.

Metropolitan Trading Company (MTC). 2012. Annual report 2011-2012.

MTC. 2010. Annual report 2009-2010.

MTC. 2005, Annual report 2004-2005.

Muhle Unlimited Designs. 2008. Master Business Plan: Linear Markets for the Inner City of Johannesburg. Report for the Metropolitan Trading Company (MTC), Johannesburg.

Republic of India. 2014. The Street Vendors (Protection of livelihood and regulation of street vending) Act, 2014.

Republic of South Africa (1991 [amended 1993]). Businesses Act. n. 71. In Government Gazette, 311 (13266). Cape Town, 24 May. 


\section{Annexure - List of acronyms}

CID City Improvement District. Bounded area where all property owners pay a specific levy (supplementary to municipal rates and taxes), to a board of local property owners (the CID board), generally to hire additional (private) security guards and cleaners. A CID can be established if a majority of the local property owners, representing a majority of the property value, have voted for its establishment. Since 2015 however, CIDs have been declared illegal; voluntary CIDs continue to exist (i.e. payment of the levy is not compulsory).

CJP Central Johannesburg Partnership. A non-profit coalition of property and business owners having a vested interest in Johannesburg inner city and its urban regeneration. It has participated in the legislation, setting up and management of CIDs in Johannesburg.

CSU Central Strategy Unit. A unit working closely to the Mayor, as advisor.

EDU Economic Development Unit, created in the early 2000s and renamed DED in 2006.

DED Department of Economic Development. A department in the City of Johannesburg, it has a unit focusing on informal trading. It leads policy and by-laws, trading restrictions and plans, demarcation of trading stalls. It oversees MTC, the agency set up to manage street traders, sign leases and collect rents.

JDA Johannesburg Development Agency. A municipal-owned entity, tasked with driving large urban development projects, in the inner city and beyond.

JMPD Johannesburg Metropolitan Police Department. JMPD is tasked with traffic and municipal by-law enforcement. Informal trading by-law infringements fall under their mandate. (NB counterfeit goods for sale are criminal offence and are the SAPS mandate).

ITF Informal Trader Forum. A forum set up in 2010, where trader organisation representatives and City officials (mostly from DED) meet on a regular basis to resolve policy and strategic issues pertaining to street trading in Johannesburg.

JPC Johannesburg Property Company. A municipal-owned entity set up in the early 2000s, with the mandate of managing land and properties owned by the City. It has taken over the management of markets and street traders from MTC in 2013 (whilst the management of taxi ranks has been returned to the City's Transport Department).

MMC Member of the Mayoral Committee - The executive arm of the City, composed of 10 members appointed by the Mayor in the governing coalition. Each MMC hold a specific portfolio.

MTC Metropolitan Trading Company. A municipal-owned entity set up in the early 2000s, with the mandate of managing markets and taxi rank infrastructures. MTC was conceived as an autonomous entity, directed by a Board of Directors but also accountable to DED, and aimed at recovering its own costs through market and taxi rentals. It was also tasked to manage street traders, with the perspective that street traders would be moved into markets. MTC was dissolved in 2013, and its functions transferred to JPC.

SAPS South African Police Service. The national police, tasked to combat and prevent crime, and maintain public order.

TTT Trading Task Team. An ad hoc committee set up by the Mayor after Operation Clean Sweep (2014) to map the way forward. It is headed by a COO (Chief Operating Officer) nominated by the Mayor, and includes officials from DED as well as the Legal, Transport and Planning departments. 